\title{
О НЕКОТОРЫХ ПРОБЛЕМАХ ПРИМЕНЕНИЯ ПРОЦЕССУАЛЬНЫХ ПОЛОЖЕНИЙ КОАП
}

\begin{abstract}
Аннотация: Автор на основе сравнительного анализа правоприменительной практики рассматривает спорные вопросы реализации ряда положений Кодекса Российской Федерации об административных правонарушениях, регулирующих порядок производства по делам об административных правонарушениях, $в$ частности проблему обжалования определений, выносимых в процессе данного производства, случаи отмены постановления по делу и возвращения дела на новое рассмотрение, а также ситуацию, когда после принятия жалобы к производству судом установлено, что обжалуемое постановление отменено вышестоящим административным органом (должностным лицом). В процессе исследования использовались методы как общенаучные (метод формальной логики, системный метод, метод анализа), так и частнонаучные (сравнительно-правовой, формально-юридический и др.). По результатам исследования предлагаются варианты решения проблемных вопросов применения процессуальных положений Кодекса Российской Федерации об административных правонарушениях, а также формулируются предложения по совершенствованию законоположений указанного Кодекса, в том числе путем восполнения имеющихся в нем пробелов правового регулирования, и унификации практики его применения.
\end{abstract}

Ключевые слова: суд, административное правонарушение, обжалование, пересмотр, определение, административный орган, процессуальное нарушение, возврат протокола, восстановление срока, меры обеспечения.

$\mathbf{E}$ жегодно судами общей юрисдикции только по первой инстанции рассматривается более 5 млн. дел об административных правонарушениях ${ }^{1}$, еще более 100 тыс. дел рассматривается арбитражными судамиํํ. При этом имеющееся правовое регулирование производства по делам об административных правонарушениях не всегда позволяет однозначно решать процессуальные вопросы, возникающие в рамках указанного производства. В данной статье предлагается рассмотреть некоторые из них.

1. Кодекс Российской Федерации об административных правонарушениях ${ }^{3}$ (далее - КоАП) не раскрывает вопрос о возможности обжалования определения о возврате протокола об административном правонарушении и других материалов дела в орган, должностному лицу, которые составили протокол.

Верховным Судом РФ по указанному вопросу дано следующее разъяснение: несмотря на то, что

\footnotetext{
1 Данные судебной статистики за 2010-2012 года // http:// www.cdep.ru/index. php?id=79\&item=1627 (27.11.2013).

2 Данные судебной статистики за 2012 года // http://arbitr. ru/_upimg/4E88EC45FB0EA F98DF89A88FF2E9DDAF_13.pdf (27.11.2013).

3 СЗ РФ. 2002. № 1. Ст. 1.
}

КоАП не предусматривает возможности обжалования указанных определений, в целях реализации конституционных положений, гарантирующих каждому право на судебную защиту, они могут быть обжалованы как исключающие возможность дальнейшего движения дела об административном правонарушении в порядке, предусмотренном КоАП ${ }^{4}$. При этом Верховный Суд РФ отметил, что возможность такого обжалования имеется только у лиц, являющихся участниками производства по делу об административном правонарушении, к числу которых не относятся органы и должностные лица, составившие протокол по делу об административном правонарушении.

Данная позиция была воспринята рядом судов нижестоящих инстанций ${ }^{5}$. Однако в практике судов общей юрисдикции встречаются и иные подходы к рассматриваемому вопросу.

\footnotetext{
4 Обзор законодательства и судебной практики Верховного Суда Российской Федерации за четвертый квартал 2007 года (утв. Постановлением Президиума Верховного Суда РФ от 27.02.2008) // Бюллетень Верховного Суда РФ. 2008. № 5.

5 См., напр., Бюллетень судебной практики Свердловского областного суда по делам об административных правонарушениях (третий квартал 2010 г.) (утв. постановлением президиума Свердловского областного суда от 27.10.2010) // СПС «КонсультантПлюс».
} 
Так, например, из определения Санкт-Петербургского городского суда следует, что указанный суд не исключает возможность обжалования указанных определений уполномоченным административным органом или его должностным лицом ${ }^{6}$. При этом Московский городской суд оставил без удовлетворения протест прокурора, являющегося согласно КоАП участником производства по делу об административном правонарушении, на определение о возврате материалов дела в связи с их неправильным оформлением, указав, что КоАП не предусматривает возможность обжалования подобных определений ${ }^{7}$. Кроме того, названный Суд отметил, что указанное определение не препятствует движению дела, поскольку при устранении недостатков, дело подлежит рассмотрению в установленном порядке, при невозможности устранения недостатков дело также может быть направлено для рассмотрения с указанием об этом.

В отношении рассматриваемого вопроса следует отметить, что нередко суды в определениях о возврате протокола об административном правонарушении и других материалов дела в орган, должностному лицу, которые составили протокол, указывают на необходимость устранения недостатков, в целом, несущественных для рассмотрения дела либо которых в действительности в протоколе нет. В подобных случаях, принимая во внимание короткие сроки давности привлечения к административной ответственности, причиной вынесения указанных определений видится, к сожалению, лишь желание суда снизить количество дел, подлежащих рассмотрению. В связи с этим на практике может сложиться ситуация, при которой суд и административный орган будут возвращать и направлять снова друг другу материалы дела об административном правонарушении вплоть до истечения срока давности привлечения к административной ответственности. Таким образом, довод о том, что рассматриваемое определение не препятствует дальнейшему движению дела, представляется малоубедительным, и следует согласиться с правомерностью разъяснений Верховного Суда РФ относительно возможности обжалования определений о возврате протокола об административном правонарушении и других

\footnotetext{
6 Определение Санкт-Петербургского городского суда от 9 октября 2012 года № 12-716/12 по делу № 5-405/12 // СПС «КонсультантПлюс».

Определение Московского городского суда от 29 июля 2010 года по делу № 7-1370/10 // СПС «КонсультантПлюс».
}

материалов дела в орган, должностному лицу, которые составили протокол.

При этом позволим себе не согласиться с подходом Верховного Суда РФ о невозможности обжалования рассматриваемого определения административным органом (должностным лицом), составившим протокол.

На первый взгляд можно предположить, что указанная позиция Верховного Суда РФ, высказанная им еще в 2008 году (до внесения изменений в КоАП, предоставивших административным органам право на обжалование постановлений по делам об административных правонарушениях (решений по жалобам на данные постановления) ${ }^{8}$ ), в настоящее время должна быть подвергнута модификации. Однако, как следует из анализа правоприменительной практики, позиция Верховного Суда РФ по данному вопросу остается неизменной. В частности в постановлении Верховного Суда РФ по конкретному делу, вынесенному уже после указанных изменений в КоАП, специально подчеркивается, что административным органам предоставлено право обжалования только постановлений по делам об административных правонарушениях 9 .

При этом подобный подход представляется непоследовательным, как минимум, с практической точки зрения. Если исходить из того, что определение о возврате протокола и других материалов дела об административном правонарушении в орган, должностному лицу, которые составили протокол, препятствует движению дела, то необходимо принимать во внимание также и то, что в ряде дел об административных правонарушениях единственным лицом, заинтересованным в дальнейшем движении дела, фактически является только административный орган (должностное лицо), его возбудивший, право которого на обжалование названного определения Верховным Судом РФ не признается.

\footnotetext{
8 Федеральный закон от 17 июля 2009 года № 160-Ф3 «О внесении изменений в Кодекс Российской Федерации об административных правонарушениях и отдельные законодательные акты Российской Федерации» // СЗ РФ. 2009. № 29. Ст. 3597; Федеральный закон от 23 июля 2010 года № 171-Ф3 «О внесении изменений в Кодекс Российской Федерации об административных правонарушениях и Федеральный закон «О промышленной безопасности опасных производственных объектов» // СЗ РФ. 2010. № 30. Ст. 4002; Федеральный закон от 18 июля 2011 года № 242-Ф3 «О внесении изменений в отдельные законодательные акты Российской Федерации по вопросам осуществления государственного контроля (надзора) и муниципального контроля» // СЗ РФ. 2011. № 30. Ст. 4590.

9 Постановление Верховного Суда РФ от 29 февраля 2012 года № 82-АД12-1 // СПС «КонсультантПлюс».
} 
В указанной ситуации повлиять на возможность дальнейшего движения дела административный орган (должностное лицо) может только путем обращения к прокурору с просьбой о принесении последним протеста на указанное определение. Однако данный механизм является средством малоэффективным, поскольку в связи с большой загруженностью органов прокуратуры и их фактической незаинтересованностью в исходе дел, возбужденных не по их инициативе, в большинстве случаев органы прокуратуры либо отказывают в принесении протеста, либо приносят его за рамками сроков давности привлечения к административной ответственности.

В результате создается ситуация, при которой административный орган имеет возможность возбудить производство по делу об административном правонарушении, но не имеет никаких реальных «механизмов влияния» на дальнейшее развитие событий по указанному делу.

Представляется, что после наделения административных органов (должностных лиц) правом на обжалование постановлений по делам об административных правонарушениях (решений по жалобам на данные постановления), следующим логичным шагом было бы предоставление указанным органам (должностным лицам) права на обжалование и иных правоприменительных решений, влияющих на движение и (или) исход дела. При этом самым оптимальным вариантом видится признание указанных субъектов полноценными участниками производства по делам об административных правонарушениях, тем более, что для отказа в принятии такого решения отсутствуют разумные объяснения.

2. КоАП также не регламентирует вопрос об обжаловании действий и решений органов и должностных лиц, связанных с применением при производстве по делам об административных правонарушениях мер обеспечения. Данный пробел правового регулирования был восполнен правовой позицией Конституционного Суда РФ, который в Определении от 18 апреля 2006 года № $107-0^{10}$ указал, что вопрос о законности указанных действий и решений может быть рассмотрен и до решения вопроса о законности постановления по делу об административном правонарушении в порядке, предусмотренном гражданским процессуальным и арбитражным процессуальным законодательством. Данная позиция Конституци-

10 Вестник Конституционного Суда РФ. 2006. № 5. онного Суда РФ в дальнейшем была воспринята в постановлении Пленума Высшего Арбитражного Суда РФ, отметившего, что указанные действия и решения могут быть обжалованы самостоятельно в порядке главы 24 Арбитражного процессуального кодекса Российской Федерации ${ }^{11}$ (далее - АПК).

Полагаем, что подобный выход был найден указанными Судами ввиду отсутствия в КоАП правовой базы для иного решения указанной проблемы. Вместе с тем вопрос о законности указанных действий и решений, как взаимосвязанных с делом об административном правонарушении, должен рассматриваться, если не совместно с указанным делом, то хотя бы в рамках схожей правовой процедуры, т.е. по правилам КоАП. В связи с этим представляется необходимым внесение в КоАП соответствующих норм, дополняющих его процедурой обжалования названных действий и решений.

Таким образом, подход Верховного Суда Р $\Phi^{12}$, воспринятый системой судов общей юрисдикции ${ }^{13}$, согласно которому вопрос о законности применения мер обеспечения производства по делу об административном правонарушении может быть рассмотрен только совместно с делом об административном правонарушении, является более правильным.

Другой вопрос, что, например, если меры обеспечения были применены в рамках административного расследования, срок проведения которого может составлять до 6 месяцев, то в рамках подхода Верховного Суда РФ вопрос об их законности будет рассмотрен значительно позднее, нежели в случае признания возможности их обжалования отдельно от дела об административном правонарушении, в связи с чем вред, причиненный лицу незаконными мерами обеспечения, может существенно возрасти.

3. На практике однозначно не решен вопрос о порядке обжалования определений, предусмотренных частью 2 статьи 29.9 КоАП. Согласно указанно-

\section{1 СЗ РФ. 2002. № 30. Ст. 3012.}

12 Пункт 7 постановления Пленума Верховного Суда РФ от 10 февраля 2009 года № 2 «О практике рассмотрения судами дел об оспаривании решений, действий (бездействия) органов государственной власти, органов местного самоуправления, должностных лиц, государственных и муниципальных служащих» // Бюллетень Верховного Суда РФ. 2009. № 4.

13 См., напр., апелляционное определение Саратовского областного суда от 22 августа 2013 года по делу № 33-5399, определение Санкт-Петербургского городского суда от 5 августа 2013 года по делу № 2-565/13 // СПС «КонсультантПлюс». 
му законоположению по результатам рассмотрения дела об административном правонарушении может быть вынесено определение о передаче дела судье, в орган, должностному лицу, уполномоченным назначать административные наказания иного вида или размера либо применять иные меры воздействия в соответствии с законодательством Российской Федерации, или о передаче дела на рассмотрение по подведомственности, если выяснено, что рассмотрение дела не относится к компетенции рассмотревших его судьи, органа, должностного лица.

Представляется, что в основу решения вопроса о надлежащем порядке обжалования указанных определений может быть положен один из двух противостоящих друг другу подходов к пониманию существа данных определений и приводящих к различным выводам о надлежащей процедуре их обжалования. Здесь, однако, следует отметить, что на практике встречается также точка зрения о том, что определение о передаче дела по подведомственности в принципе невозможно обжаловать ${ }^{14}$.

Первый из упомянутых подходов исходит из того, что указанные определения представляют собой документ, принятый по итогам рассмотрения дела, и потому подлежит обжалованию в той же процедуре, что и постановление по делу об административном правонарушении. Видимо, из указанного подхода исходил, в частности, Суд Чукотского автономного округа ${ }^{15}$, пересмотрев определение о передаче дела по подведомственности, вынесенное по итогам рассмотрения дела, в порядке главы 30 КоАП.

При этом представляется более верным другой возможный подход к рассматриваемому вопросу, согласно которому указанные определения следует рассматривать не как итоговые документы по делу, поскольку содержащиеся в них выводы не предрешают исход рассматриваемых дел, а как документы промежуточные, вынесение которых не препятствует движению дел, в рамках которых они были вынесены. При таком подходе указанные определения могут быть обжалованы только совместно с итоговыми постановлениями по делам об административных правонарушениях ${ }^{16}$.

14 Постановление Московского городского суда от 12 ноября 2012 года № 4a-3062/12 // СПС «КонсультантПлюс».

15 Определение суда Чукотского автономного округа от 6 декабря 2011 года № 7-12/11 по делу № 5-10/11 // СПС «КонсультантПлюс».

16 Как показывает анализ практики судов общей юрисдикции московского региона, вопрос о законности и (или)
Кроме того, следует отметить, что обжалование любого из названных определений до рассмотрения дела об административном правонарушении по существу потребует приостановления производства по указанному делу и может привести к тому, что на момент рассмотрения дела об административном правонарушении по существу сроки давности привлечения к административной ответственности окажутся истекшими ${ }^{17}$.

4. Согласно части 1 статьи 30.3 КоАП жалоба на постановление по делу об административном правонарушении может быть подана в течение десяти суток со дня вручения или получения копии постановления.

Срок на обжалование постановления не является пресекательным и может быть восстановлен в случае его пропуска по ходатайству лица, подающего жалобу или протест (часть 2 статьи 30.3, часть 1 статьи 30.10 КоАП).

При этом ряд специалистов полагают, что срок на обжалование постановления по делу может быть восстановлен без каких-либо временных ограничений ${ }^{18}$. Полагаем, что подобный вывод противоречит требованиям определенности, стабильности и предсказуемости правового положения лиц, участвующих в деле, о необходимости соблюдения которых неоднократно высказывался Конституци-

обоснованности рассматриваемых определений в большинстве своем исследуется совместно с рассмотрением постановления по делу об административном правонарушении (см., напр., постановление Московского городского суда от 4 марта 2010 года по делу № 4a-4238/09; постановление Московского городского суда от 14 июля 2008 года по делу № 4а-1988/08 // СПС «КонсультантПлюс»).

17 Безусловно, здесь можно возразить, что в случае обжалования любого из рассматриваемых определений совместно с постановлением по делу об административном правонарушении и отмены последнего ввиду нарушения правил подведомственности (подсудности), сроки давности привлечения к административной ответственности также, скорее всего, окажутся истекшими, что не позволит в дальнейшем рассмотреть вопрос о привлечении деликвента к административной ответственности. Но следует учитывать, что при предлагаемом в данной статье подходе шансов на то, что вопрос о привлечении лица к административной ответственности будет разрешен в рамках срока давности привлечения к административной ответственности и постановление по делу об административном правонарушении не будет в дальнейшем отменено всё таки больше, нежели в случае признания возможности самостоятельного обжалования определений, указанных в части 2 статьи 29.9 КоАП.

18 См., напр., Дугенец А.С. Административная ответственность в российском праве: Дисс. ... докт. юрид. наук: 12.00.14. M., 2005. C. 281. 
онный Суд РФ в своих решениях ${ }^{19}$. В связи с этим представляется, что законодателю надлежит установить конкретный срок, в рамках которого возможно восстановление срока на обжалование.

В литературе высказываются также различные точки зрения относительного того, должны ли причины пропуска срока на подачу жалобы являться уважительными или нет, поскольку КоАП не содержит специального указания по данному вопросу.

Так, одни авторы полагают, что неуважительность причин пропуска указанного срока не может являться основанием для отказа в удовлетворении жалобы при очевидной ошибочности постановления, но она должна учитываться при разрешении жалобы по существу в совокупности с другими основаниям ${ }^{20}$. На практике также встречаются судебные решения, в которых суд приходит к аналогичному выводу. В частности указывается, что исходя из необходимости обеспечения конституционного права на судебную защиту и принимая во внимание возможную недостаточную юридическую осведомленность гражданина о порядке подачи жалобы, неуказание в ходатайстве причин пропуска срока на обжалование постановления по делу не может являться обстоятельством, препятствующем восстановлению судом срока на обжалование ${ }^{21}$.

Другие специалисты указывают, что рассматриваемый срок может быть восстановлен только в случае признания причин его пропуска уважительными, поскольку иное допускает возможность злоупотреблений со стороны недобросовестных деликвентов ${ }^{22}$.

На необходимость в данном случае признания причин пропуска срока на обжалование уважительными указывается и в разъяснениях Верховного Суда РФ. В числе причин, которые могут быть

\footnotetext{
19 См., напр., Определение Конституционного Суда РФ от 9 ноября 2010 года № 1469-О-О // СПС «КонсультантПлюс».

20 Дугенец А.С. Указ. соч. С. 282; Дугенец А.С., Масленников М.Я. Гарантии законности производстве по делам об административных правонарушениях // Научный портал МВД России. 2011. № 2. С. 10; Масленников М.Я. Административно-юрисдикционный процесс. Сущность и актуальные вопросы правоприменения по делам об административных правонарушениях. Воронеж. Изд-во Воронежского университета. 1990. С. 137 - 138.

21 Решение Ленинградского областного суда от 26 апреля 2011 года № 7-274/2011 // СПС «КонсультантПлюс».

22 Головко В.В., Москаленко С.С. Пересмотр постановлений по делу об административном правонарушении // Российская юстиция. 2007. № 1.
}

признаны уважительными, Верховный Суд ${ }^{23}$ прямо называет только болезнь лица, дополняя данный «перечень» словами «и т.п.»»

В литературе же указывается, что на практике уважительными причинами признаются также временный выезд с постоянного места жительства, стечение семейных обстоятельств, недостаточная юридическая осведомленность гражданина о порядке подачи жалоб ${ }^{25}$.

Признание уважительной для целей восстановления срока на обжалование постановления по делу последней из перечисленных причин вызывает некоторые сомнения. Безусловно, при решении вопроса о признании той или иной причины пропуска срока на обжалование постановления по делу уважительной необходимо учитывать обстоятельства каждого конкретного дела, однако подход, при котором уважительной причиной признается незнание законов, представляется слишком расширительным. При таком подходе установление критерия «уважительности» становится не более, чем фикцией. Кроме того в соответствии с частью 3 статьи 15 Конституции Р $\Phi^{26}$, согласно которой законы в России подлежат официальному опубликованию для всеобщего сведения, в нашей стране действует презумпция знания законов, и незнание законов не может быть признано смягчающим обстоятельством или уважительной причиной.

Полагаем, что уважительными причинами пропуска срока на обжалование могут быть признаны только «обстоятельства объективного характера, не зависящие от заявителя и находящиеся вне его контроля», случившиеся «при соблюдении им той степени заботливости и осмотрительно-

23 Обзор законодательства и судебной практики Верховного Суда РФ за третий квартал 2003 г. (Бюллетень Верховного Суда РФ. 2004. № 3. С. 27).

24 Данное разъяснение, безусловно, не вносит существенной ясности, вследствие чего в литературе отмечается необходимость дачи более развернутого перечня причин, которые могут быть признаны уважительными (Масленников М.Я. Порядок пересмотра судами общей юрисдикции постановлений по делам об административных правонарушениях // Российский судья. 2004. № 10).

25 Масленников М.Я. Порядок пересмотра судами общей юрисдикции постановлений по делам об административных правонарушениях // Российский судья. 2004. № 10; Постатейный комментарий к Кодексу РФ об административных правонарушениях / Д.С. Велиева, А.С. Ермакова, Ю.В. Капитанец и др.; под ред. Э.Г. Липатова, С.Е. Чаннова. М.: ГроссМедиа, РОСБУХ, 2008. 912 с.

26 СЗ РФ. 2009. № 4. Ст. 445. 
сти, какая требовалась от него в целях соблюдения установленного порядка» ${ }^{27}$. Подобный подход к пониманию критериев уважительности пропуска срока на обжалование предусмотрен в части 2 статьи 259 АПК и в Гражданском процессуальном кодексе Российской Федерации ${ }^{28}$ (далее - ГПК) ${ }^{29}$, и, как представляется, с полным правом может быть применен и к регламентации рассматриваемого вопроса в КоАП.

В случае отказа в удовлетворении ходатайства о восстановлении срока для обжалования постановления по делу выносится определение, которое, как препятствующее дальнейшему движению дела, может быть обжаловано ${ }^{30}$.

Вместе с тем специалисты отмечают, что в данном случае остается не вполне понятным, в рамках какой процедуры может быть обжаловано данное определение, поскольку КоАП данный вопрос не регулирует $^{31}$. Причем иногда в литературе предлагается применять для рассмотрения данных определений положения главы 25 «Производство по делам об оспаривании решений, действий (бездействия) органов государственной власти, органов местного самоуправления, должностных лиц, государственных и муниципальных служащих» ГПК ${ }^{32}$

27 Постановление Федерального арбитражного суда Северо-Кавказского округа от 3 июля 2013 года по делу № А 32-22768/2012, постановление Двадцатого арбитражного апелляционного суда от 15 февраля 2012 года по делу № А62-5123/2011 // СПС «КонсультантПлюс».

28 СЗ РФ. 2002. № 46. Ст. 4532.

29 Пункт 8 постановление Пленума Верховного Суда РФ от 19 июня 2012 года № 13 «О применении судами норм гражданского процессуального законодательства, регламентирующих производство в суде апелляционной инстанции» // Бюллетень Верховного Суда РФ. 2012. № 9.

30 Обзор судебной практики за 3 квартал 2003 года // Бюллетень Верховного Суда РФ. 2004. № 3. С. 26; пункт 31 Постановления Пленума Верховного Суда РФ от 24 марта 2005 года № 5 «О некоторых вопросах, возникающих у судов при применении Кодекса Российской Федерации об административных правонарушениях» // Бюллетень Верховного Суда РФ. 2005. № 6.

31 Панкова О.В. Актуальные проблемы обжалования постановлений по делам об административных правонарушениях в практике судов общей юрисдикции // Административное право и процесс. 2005. № 3.

32 Лаврентьев А.Р. Об обжаловании в суд постановлений и решений по делам об административных правонарушениях // Антология научной мысли: К 10-летию Российской академии правосудия: Сборник статей / Отв. ред. В.В. Ершов, Н.А. Тузов. М.: Статут, 2008. С. $473-493$ // СПС «КонсультантПлюс». или, видимо, положения главы 24 АПК, регламентирующих процедуру оспаривания ненормативных правовых актов в арбитражных судах.

Данное предложение представляется не совсем обоснованным. Полагаем, что вопрос о законности указанного определения, как взаимосвязанного с делом об административном правонарушении, должен рассматриваться в единой процедуре с указанным делом, т.е. по правилам КоАП. При этом, как показывает анализ правоприменительной практики, суды общей юрисдикции в большинстве своем также применяют именно положения КоАП ${ }^{33}$ при рассмотрении жалоб на указанные определения, причем некоторые специально акцентируют внимание на то, что названные определения обжалуются по тем же правилам КоАП, что и постановления по делам об административных правонарушениях ${ }^{34}$.

5. Также на практике возникает вопрос относительно того, как должен поступить суд в случае, если после принятия жалобы к производству было установлено, что обжалуемое постановление отменено вышестоящим административным органом (должностным лицом).

Подобная проблема выявлена в практике арбитражных судов. Вместе с тем представляется, что она также актуальна и для судов общей юрисдикции, однако ввиду отсутствия в широком доступе полной базы решений судов общей юрисдикции невозможно подтвердить или опровергнуть данный тезис.

На практике сложились два основных подхода к решению указанной проблемы.

Первый подход исходит из того, что отмена оспариваемого постановления о привлечении к административной ответственности вышестоящим административным органом (должностным лицом) не является основанием, исключающим возможность признания его незаконным в судебном

33 Письмо Пермского областного суда от 14 октября 2002 года № 05-17-1 «Методические рекомендации по отдельным вопросам применения Кодекса РФ об административных правонарушениях», Определение Суда Ненецкого автономного округа от 18 июня 2012 года по делу № 7-18/2012, постановление Московского городского суда от 20 августа 2012 года № 4а-1392/12, определение Московского городского суда от 26 июля 2012 года по делу № 7-1431/12, определение Верховного Суда РФ от 28 апреля 2010 года № 53-Г10-4 // СПС «КонсультантПлюс».

34 Постановление Хабаровского краевого суда от 20 сентября 2013 года № 4-А-500/13, постановление Хабаровского краевого суда от 20 сентября 2013 года № 4-А-499/13 // СПС «КонсультантПлюс». 
порядке ${ }^{35}$. Обоснование подобного подхода строится на положении части 2 статьи 30.1 КоАП, согласно которому в случае, если жалоба на постановление по делу об административном правонарушении поступила в суд и в вышестоящий административный орган (вышестоящему должностному лицу), она подлежит рассмотрению судом.

Сторонники второго подхода полагают, что в данном случае дело подлежит прекращению судом в связи с отсутствием спора ${ }^{36}$.

Представляется, что последний подход к решению указанного вопроса более обоснован и целесообразен, поскольку на момент рассмотрения судом соответствующей жалобы постановление по делу уже отменено вышестоящим административным органом (должностным лицом) и, следовательно, не может быть исполнено. В связи с этим нарушение прав и законных интересов заявителя отсутствует, также как и предмет судебного рассмотрения.

При этом полагаем, что подобные рассуждения и указанный подход не входят в противоречие с положением части 2 статьи 30.1 КоАП, поскольку последнее, как представляется, рассчитано на предотвращение споров о подведомственности и ситуацию, когда жалобы в суд и в вышестоящий административный орган (вышестоящему должностному лицу) поданы одновременно и данный факт выявлен до рассмотрения жалобы по существу каким-либо из указанных субъектов правоприменения.

6. В соответствии со статьей 30.7 КоАП по результатам рассмотрения жалобы на постановление по делу об административном правонарушении может быть принято одно из нескольких решений, в частности об отмене постановления и о возвращении дела на новое рассмотрение судье (в орган, должностному лицу), управомоченному рассмотреть дело (пункт 4 части 1).

Решение об отмене постановления и о возвращении дела на новое рассмотрение судье (в орган,

35 Постановление Девятого арбитражного апелляционного суда от 22 января 2013 года по делу № А40-66316/12-21-634; постановление ФАС Дальневосточного округа от 29 апреля 2010 года № Ф03-2624/2010; постановление Четвертого арбитражного апелляционного суда от 22 апреля 2009 года по делу № А58-8601/08; постановления ФАС Западно-Сибирского округа от 26 апреля 2007 года № Ф04-2528/2007(33703А46-29), от 25 октября 2007 года № Ф04-7560/2007(396628А45-29) // СПС «КонсультантПлюс».

36 Постановление Тринадцатого арбитражного апелляционного суда от 12 августа 2010 года по делу № А56-8398/2010 // СПС «КонсультантПлюс». должностному лицу), управомоченному рассмотреть дело, принимается в двух случаях:

- $\quad$ если в процессе рассмотрения жалобы будут установлены существенные нарушения процессуальных требований КоАП, допущенные при рассмотрении дела по существу и не позволившие всесторонне, полно и объективно рассмотреть дело;

- $\quad$ если потерпевшим по делу подана жалоба на мягкость примененного административного наказания и в процессе ее рассмотрения признано необходимым применение закона об административном правонарушении, влекущем назначение более строгого административного наказания.

Относительно первого случая необходимо отметить, что официальной или устоявшейся позиции относительно того, что следует понимать под существенными нарушениями процессуальных требований, не имеется. В связи с этим вопрос о наличии или отсутствии таковых нарушений должен решаться уполномоченным на пересмотр постановления (решения) по делу судом (органом, должностным лицом) по собственному усмотрению на основании обстоятельств дела. Однако как отмечается в литературе, указанные субъекты правоприменения пользоваться данной нормой опасаются ${ }^{37}$, вследствие чего необходимы разъяснения по данному вопросу Верховного Суда $Р \Phi^{38}$.

Как представляется, не всякое процессуальное нарушение может и должно признаваться существенным ${ }^{39}$. Нарушение следует признавать существенным, когда не достигнуты задачи административного производства, т.е. дело не рассмотрено всестороннее, полно и объективно (на данный критерий указывает и сам Закон), а также в случае, когда данное нарушение повлекло «ощутимое умаление» принципов административного

37 Козлов С.С., Куратов А.А. Процессуальные особенности пересмотра административных дел судами общей юрисдикции: проблемы теории и практики // Российский судья. 2010. № 1. C. $4-6$.

38 Кодзаев Ч.С. Пересмотр постановлений по делам об административных правонарушениях: Автореф. дисс. ... канд. юрид. наук: 12.00.14. Ростов-на-Дону. 2010. С. 9; Масленников М.Я. Порядок пересмотра судами общей юрисдикции постановлений по делам об административных правонарушениях // Российский судья. 2004. № 10.

39 В литературе процессуальные нарушения иногда подразделяют на формальные, существенные и безусловные, т.е. полагают, что последние две характеристики нарушений не являются тождественными (Кодзаев Ч.С. Указ. соч. С. 23). 
процесса или прав участников производства ${ }^{40}$ (например, в случае нарушения правил подсудности нарушается конституционное право лица на рассмотрение его дела компетентным судом).

Таким образом, главным критерием существенности допущенного нарушения выступает не само нарушение, как иногда указывается в литературе $^{41}$, а значимость его последствий.

Относительно второго случая, необходимо отметить следующее. Верховный Суд РФ в своих разъяснениях специально отметил, что не вступившее в законную силу постановление по делу об административном правонарушении может быть отменено в связи с необходимостью применения закона об административном правонарушении, влекущем назначение более строгого административного наказания, только в одном случае - когда потерпевшим по делу подана жалоба на мягкость примененного административного наказания ${ }^{42}$.

В литературе, однако, высказываются за расширительное толкование рассматриваемой нормы. Так, предлагается распространять данную норму и на случаи обжалования постановлений о прекращении производства по делам, вынесенным ввиду отсутствия события или состава административного правонарушения, или действия лица в состоянии крайней необходимости, а также на прокуроров, предоставив им право также ставить вопрос о повороте к худшему ${ }^{43}$.

Однако если с первым предложением еще можно согласиться, то правомерность второго - вызывает сомнения. Приводимая в его обоснование статья 30.10 КоАП, согласно которой на прокурора при принесении им протеста на не вступившее в законную силу постановление по делу распро-

\footnotetext{
40 Подвальный И.О. К вопросам административного судопроизводства, возникающим в практике арбитражных судов // Арбитражные споры. 2012. № 1. С. 51 - 69 .

41 Например, некоторые авторы полагают, что существенным должно признаваться, в числе прочего, нарушение правил рассмотрения заявленного ходатайства, а именно невынесение в случае отклонения ходатайства определения, а фиксация данного отказа в итоговом решении по делу (Козлов С.С., Куратов А.А. Указ. соч.).

42 Обзор законодательства и судебной практики Верховного Суда Российской Федерации за четвертый квартал 2007 года (утв. постановлением Президиума Верховного Суда Российской Федерации от 27 февраля 2008 года // Бюллетень Верховного Суда РФ. 2008. № 5.

43 Шагабутдинов А.А. Поворот к худшему при пересмотре постановления, решений по делу об административном правонарушении // Российский судья. 2005. № 6.
}

страняются общий порядок и сроки обжалования постановления, не затрагивает вопроса пределов обжалования постановления по делу. Кроме того, если следовать логике автора, отстаивающего рассматриваемый подход, необходимо прийти к выводу, что аналогичное право должно быть предоставлено также и административному органу, поскольку в силу части 1.1 статьи 30.1 и части 5 статьи 30.9 КоАП его право на обжалование реализуется на основании тех же законоположений, что и право потерпевшего, без каких-либо изъятий.

Следует отметить, что формулировка пункта 4 части 1 статьи 30.7 КоАП, а также толкование его положений, данное Верховным Судом РФ, отнюдь не означает, что поворот к худшему при новом рассмотрении дела возможен только в случае, если новое рассмотрение инициировано по жалобе потерпевшего на мягкость наказания.

Положение пункта 4 части 1 статьи 30.7 КоАП устанавливает два основания для возврата дела на новое рассмотрение, в том числе выявление при рассмотрении жалобы существенных нарушений процессуальных требований, допущенных при рассмотрении дела по существу. Данное основание может быть выявлено при рассмотрении жалобы любого лица, имеющего право на обжалование постановления по делу об административном правонарушении, в том числе деликвента.

При новом рассмотрении дело рассматривается по существу по правилам главы 29 КоАП без каких либо ограничений. Не действуют в данном случае и правила пункта 2 части 1 статьи 30.7 КоАП относительно невозможности ухудшения положения деликвента.

Данный вывод следует из существа данной стадии, именно как нового производства по делу (а не пересмотра состоявшегося решения), в рамках которого, ввиду отмены вынесенного постановления по делу, лицо, совершившее правонарушение, является привлекаемым, но не привлеченным к административной ответственности. Следовательно, по результатам рассмотрения дела может быть вынесено любое постановление или определение из числа предусмотренных статьей 29.9 КоАП, в том числе о привлечении к административной ответственности, и назначено наказание, которое по сравнению с наказанием, назначенным деликвенту в «прошлый раз» отмененным постановлением, может оказаться более строгим. При новом рассмотрении дела назначение наказания осуществляется не судом или органом (должностным лицом), рассматривающим жалобу, запрет на назначение которым более стро- 
го наказания установлен в пункте 2 части 1 статьи 30.7 КоАП, а судом или органом (должностным лицом), уполномоченным на рассмотрение дела по существу, при новом рассмотрении данного дела, на которых действие указанной нормы не распростра- няется. При этом, однако, как отмечается в литературе, на практике имели место случаи применения пункта 2 части 1 статьи 30.7 КоАП при новом рассмотрении дела ${ }^{44}$, что ввиду изложенного представляется необоснованным.

\section{Библиография:}

1. Абсалямов А.В. Административное судопроизводство в арбитражном суде. Теоретико-методологические аспекты: Дисс. ... докт. юрид. наук: 12.00.14. Москва. 2009.

2. Головко В.В., Москаленко С.С. Пересмотр постановлений по делу об административном правонарушении // Российская юстиция. 2007. № 1.

3. Дугенец А.С. Административная ответственность в российском праве: Дисс. ... докт. юрид. наук: 12.00.14. М., 2005.

4. Дугенец А.С., Масленников М.Я. Гарантии законности производстве по делам об административных правонарушениях // Научный портал МВД России. 2011. № 2.

5. Кодзаев Ч.С. Пересмотр постановлений по делам об административных правонарушениях: Автореф. дисс. ... канд. юрид. наук: 12.00.14. Ростов-на-Дону. 2010.

6. Козлов С.С., Куратов А.А. Процессуальные особенности пересмотра административных дел судами общей юрисдикции: проблемы теории и практики // Российский судья. 2010. № 1.

7. Лаврентьев А.Р. Об обжаловании в суд постановлений и решений по делам об административных правонарушениях // Антология научной мысли: К 10-летию Российской академии правосудия: Сборник статей / Отв. ред. В.В. Ершов, Н.А. Тузов. М.: Статут, 2008. С. 473-493 // СПС «КонсультантПлюс».

8. Масленников М.Я. Административно-юрисдикционный процесс. Сущность и актуальные вопросы правоприменения по делам об административных правонарушениях. Воронеж. Изд-во Воронежского университета. 1990.

9. Масленников М.Я. Порядок пересмотра судами общей юрисдикции постановлений по делам об административных правонарушениях // Российский судья. 2004. № 10; Постатейный комментарий к Кодексу РФ об административных правонарушениях / Д.С. Велиева, А.С. Ермакова, Ю.В. Капитанец и др.; под ред. Э.Г. Липатова, С.Е. Чаннова. М.: ГроссМедиа, РОСБУХ, 2008.

10. Масленников М.Я. Порядок пересмотра судами общей юрисдикции постановлений по делам об административных правонарушениях // Российский судья. 2004. № 10.

11. Панкова О.В. Актуальные проблемы обжалования постановлений по делам об административных правонарушениях в практике судов общей юрисдикции // Административное право и процесс. 2005. № 3.

12. Подвальный И.О. К вопросам административного судопроизводства, возникающим в практике арбитражных судов // Арбитражные споры. 2012. № 1.

13. Хазанов С.Д. Общая характеристика стадии пересмотра в производстве по делам об административных правонарушениях // Журнал российского права. 2004. № 10.

14. Шагабутдинов А.А. Поворот к худшему при пересмотре постановления, решений по делу об административном правонарушении // Российский судья. 2005. № 6

\section{References (transliterated):}

1. Absalyamov A.V. Administrativnoe sudoproizvodstvo v arbitrazhnom sude. Teoretiko-metodologicheskie aspekty: Diss. ... dokt. yurid. nauk: 12.00.14. Moskva. 2009.

\footnotetext{
44 Абсалямов А.В. Административное судопроизводство в арбитражном суде. Теоретико-методологические аспекты: Дисс. ... докт. юрид. наук: 12.00.14. Москва. 2009. С. 262; Хазанов С.Д. Общая характеристика стадии пересмотра в производстве по делам об административных правонарушениях // Журнал российского права. 2004. № 10.
} 
2. Golovko V.V., Moskalenko S.S. Peresmotr postanovlenii po delu ob administrativnom pravonarushenii // Rossiiskaya yustitsiya. 2007. № 1.

3. Dugenets A.S. Administrativnaya otvetstvennost' v rossiiskom prave: Diss. ... dokt. yurid. nauk: 12.00.14. M., 2005.

4. Dugenets A.S., Maslennikov M.Ya. Garantii zakonnosti proizvodstve po delam ob administrativnykh pravonarusheniyakh // Nauchnyi portal MVD Rossii. 2011. № 2.

5. Kodzaev Ch.S. Peresmotr postanovlenii po delam ob administrativnykh pravonarusheniyakh: Avtoref. diss. ... kand. yurid. nauk: 12.00.14. Rostov-na-Donu. 2010.

6. Kozlov S.S., Kuratov A.A. Protsessual'nye osobennosti peresmotra administrativnykh del sudami obshchei yurisdiktsii: problemy teorii i praktiki // Rossiiskii sud'ya. 2010. № 1.

7. Lavrent'ev A.R. Ob obzhalovanii $\mathrm{v}$ sud postanovlenii i reshenii po delam ob administrativnykh pravonarusheniyakh // Antologiya nauchnoi mysli: K 10-letiyu Rossiiskoi akademii pravosudiya: Sbornik statei / Otv. red. V.V. Ershov, N.A. Tuzov. M.: Statut, 2008. S. 473-493 // SPS «Konsul'tantPlyus».

8. Maslennikov M.Ya. Administrativno-yurisdiktsionnyi protsess. Sushchnost' i aktual'nye voprosy pravoprimeneniya po delam ob administrativnykh pravonarusheniyakh. Voronezh. Izd-vo Voronezhskogo universiteta. 1990.

9. Maslennikov M.Ya. Poryadok peresmotra sudami obshchei yurisdiktsii postanovlenii po delam ob administrativnykh pravonarusheniyakh // Rossiiskii sud'ya. 2004. № 10; Postateinyi kommentarii k Kodeksu RF ob administrativnykh pravonarusheniyakh / D.S. Velieva, A.S. Ermakova, Yu.V. Kapitanets i dr.; pod red. E.G. Lipatova, S.E. Channova. M.: GrossMedia, ROSBUKh, 2008.

10. Maslennikov M.Ya. Poryadok peresmotra sudami obshchei yurisdiktsii postanovlenii po delam ob administrativnykh pravonarusheniyakh // Rossiiskii sud'ya. 2004. № 10.

11. Pankova O.V. Aktual'nye problemy obzhalovaniya postanovlenii po delam ob administrativnykh pravonarusheniyakh v praktike sudov obshchei yurisdiktsii // Administrativnoe pravo i protsess. 2005. № 3.

12. Podval'nyi I.O. K voprosam administrativnogo sudoproizvodstva, voznikayushchim v praktike arbitrazhnykh sudov // Arbitrazhnye spory. 2012. № 1.

13. Khazanov S.D. Obshchaya kharakteristika stadii peresmotra v proizvodstve po delam ob administrativnykh pravonarusheniyakh // Zhurnal rossiiskogo prava. 2004. № 10.

14. ShagabutdinovA.A.Povorotkkhudshemu pri peresmotre postanovleniya, reshenii po delu obadministrativnom pravonarushenii // Rossiiskii sud'ya. 2005. № 6 